The terminus of the Grinnell Glacier was mapped in 1945, 1947, 1950, 1951 and 1952. The period 1945 to $195^{\circ}$ showed some recession but the amount was small. In I95 I there was a sligh. advance of the terminus and in $195^{2}$ a slight recession to essentially the same position occupied in 1950. A few random observations in 1953, 1954 and 1955 indicate that no significant changes have occurred. The variations of the terminus within the ten-year period, 1945-55, were within such narrow limits that they cannot be considered as indicating either recession or advance but rather as verifying the state of equilibrium indicated by the cross-profile measurements.

It is of noteworthy interest that during the decade, I945 to 1955 , there was a pronounced thickening of the Nisqually Glacier whereas the Sperry and Grinnell Glaciers have more nearly maintained a condition of balance. This verifies Professor Harrison's statement that parallelism in behavior of the glaciers in different parts of the country does not necessarily exist.

\title{
FURTHER NOTE ON THE NISQUALLY GLACIER, MOUNT RAINIER, WASHINGTON
}

\section{By A. E. Harrison}

SOME questions have been raised regarding the interpretation of the paper by V. R. Bender and A. L. Haines entitled "Forty-two years of recession of the Nisqually Glacier on Mount Rainier" in Erdkunde, Bd. 9, Ht. 4, 1955, p. $275-8 \mathrm{r}$, with relation to the paper by the present writer on "Fluctuation of the Nisqually Glacier, Mt. Rainier, Washington, since $175^{\circ}$ " in the Fournal of Glaciology, Vol. 2, No. 19 , 1956, p. $675^{-83}$. Actually the two papers are in agreement, but it may be worth while to point out some of the implications of the fluctuations and add some estimates of their effect on the data published by Bender and Haines.

Mention is made by Hofmann (Erdkunde, Bd. 9, Ht. 4, 1955, p. 28I-86) of the increased thickness observed on the Nisqually Glacier during the last decade. This increase was detected by Arthur Johnson of the United States Geological Survey after 1945, and an estimate of the volume involved can be obtained from the cross-profile measurements included in Johnson's progress reports on file at the United States Geological Survey in Washington, D.C.

An area of approximately $\mathrm{I} \mathrm{km}^{2}$ is included in the region covered by the cross-profiles, and the increase in volume over this area between 1945 and $195^{\circ}$ was about $12,000,000 \mathrm{~m} .{ }^{3}$. The area above the profiles includes about $4.8 \mathrm{~km}^{2}$. The accumulation at the highest levels is probably less, and some of the accumulation has moved downward to produce the growth in the profile region, so it is logical to assume a proportionately smaller increase of volume the higher levels. This increase has been estimated as $24,000,000 \mathrm{~m} .{ }^{3}$. Deducting an estimated shrinkage of $1,000,000 \mathrm{~m} .{ }^{3}$ in the area of stagnant ice below the profiles gives a net growth of $35,000,000 \mathrm{~m} .{ }^{3}$ for the Nisqually Glacier during the five-year period between 1945 and $195^{\circ}$. This estimate is probably low.

Shrinkage returned temporarily in $195^{1}$ and $195^{2}$. The year $195^{2}$ was particularly destructive. A loss of I $_{5}, 000,000 \mathrm{~m} \cdot{ }^{3}$ has been estimated for the two years from the appearance of landmarks in photographs made in these years. This loss in volume leaves a net growth of $20,000,000 \mathrm{~m} .^{3}$ between 1945 and 1952 .

Consideration of these estimated data changes the story of the recession of the Nisqually Glacier somewhat. The total loss is greater and the period of the shrinkage is shorter. Actually, the period of shrinkage is even less than thirty-five years. The Nisqually Glacier did not shrink appreciably in volume until after 1920 . This conclusion is based on an inspection of old photo- 
graphs. Also, a period of growth occurred between $193 \mathrm{I}$ and 1936 , and built a small moraine just below the "protuberance" mentioned by Hofmann. This moraine was recently destroyed by the newest "wave" of ice moving down the glacier. In view of these factors, the loss in volume should be increased from $12 \mathrm{I}, 000,000 \mathrm{~m} \cdot{ }^{3}$ to $\mathrm{I} 4 \mathrm{I}, 000,000 \mathrm{~m} \cdot{ }^{3}$, most of which melted during a period of twenty years. The average annual loss in volume during the years of appreciable shrinkage is comparable to the estimated loss during $195^{1}$ and $195^{2}$.

A few other observations regarding the review of previous investigations may be of interest. The fact that S. F. Emmons and A. D. Wilson (American Fournal of Science, Vol. I (3rd ser., I87 I, p. $16 \mathrm{I}-65$ ) failed to recognize a recessional trend in 1870 is not surprising, since the retreat between 1857 and 1870 was slight and the description of the position of the terminus by A. V. Kautz in 1857 could apply almost as well to the location observed by Emmons and Wilson. As pointed out by the writer in the article on fluctuations of the Nisqually Glacier, unprecedented shrinkage occurred during the decade after I884. Russell's party ("Glaciers of Mt. Rainier" I 8 th Annual Report of the U.S. Geological Survey, Part 2, 1897, p. 407) could hardly fail to observe the results of this shrinkage in 1896 , although climatic conditions had already changed and a new wave of ice must have been on its way down the mountain at that time.

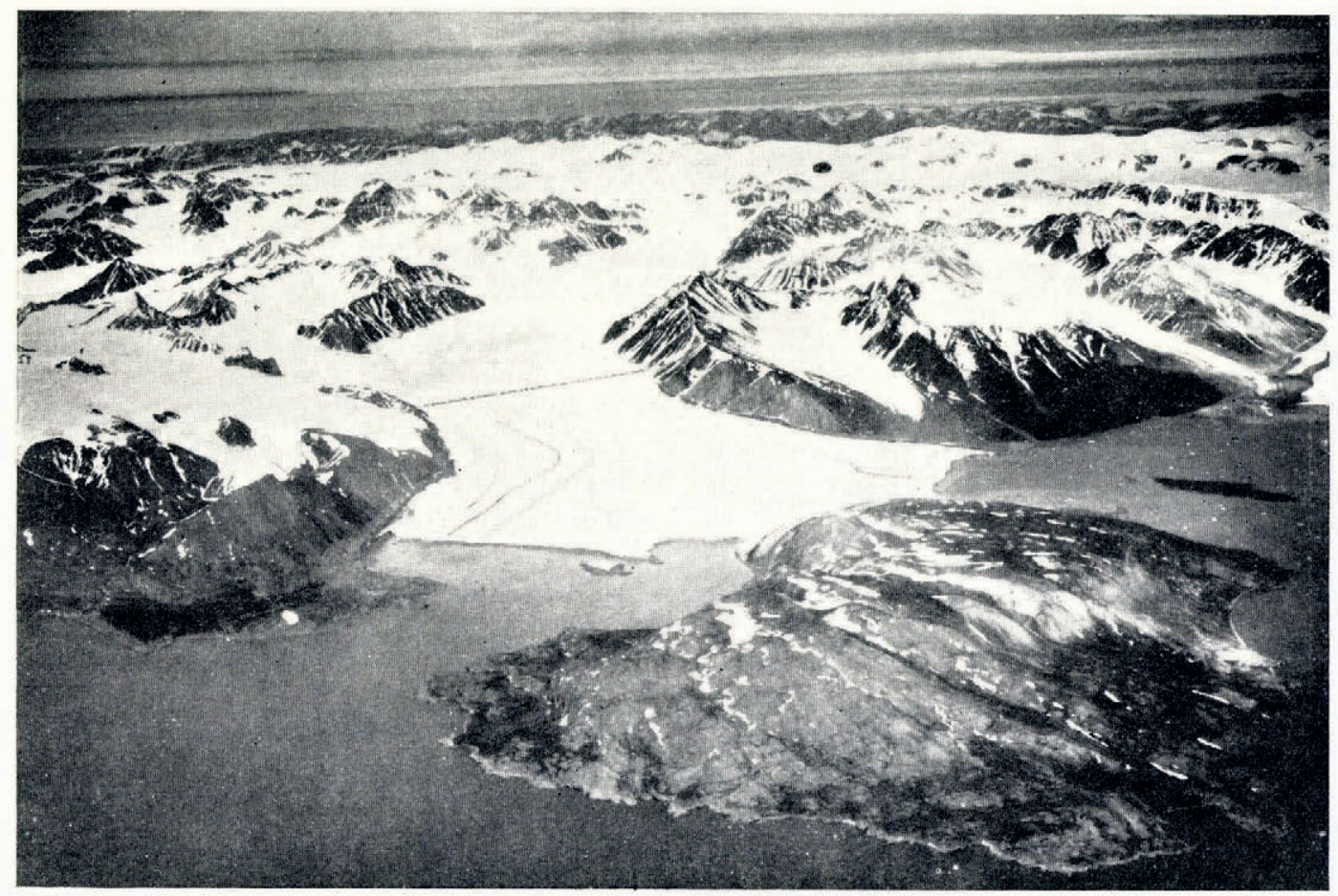

Fig. 7. Blomstrandhreen. The line indicates the position of the stakes; the black spot the position of the firn pit on Isachsenfonna (see .M. Mellor, D. oit) 